\title{
The Construction of Teacher Evaluation System in Applied Undergraduate College Based on Modern Education Technology
}

\author{
Lijuan Bai \\ Heilongjiang Finance and Economics Institute \\ Harbin, China 150025
}

\begin{abstract}
Based on the actual situation of the applicationoriented colleges and universities, this paper analyzes the existing problems of teacher evaluation work and proposes improvement measures based on the questionnaire survey. And then, it completes the theoretical construction of the teacher evaluation system. In order to comply with the development needs of current science and technology, this study takes modern educational technology as an observation point for teacher evaluation and incorporates the "development" index into the teacher evaluation system to make it more objective, scientific, fair, and comprehensive. And then, it would promote the innovation of teacher evaluation and achieve the goal of "teacher development".
\end{abstract}

Keywords - teacher evaluation; teacher development; modern education technology; applied undergraduate college

\section{INTRODUCTION}

The university undertakes the historic mission of personnel training, scientific research, social services, and cultural heritage and innovation. In order to ensure the precise demand for talents in today's economic and social development, it is imperative that applied undergraduate colleges must create a team of teachers with factors such as moral integrity, good quality, sufficient numbers, reasonable structure, and relative stability. And it would ensure the development of applied undergraduate institutions. The construction of the teaching team focuses on stimulating the enthusiasm, initiative and self-consciousness of teachers' professional development. It should enhance teachers' professional identity and professional ability. Teacher evaluation is one of the necessary means. Based on the actual situation of the application-oriented colleges and universities, this paper analyzes the current status and existing problems of the current teacher evaluation work, proposes targeted improvement measures, and builds the teacher evaluation system of application undergraduate college that incorporates the "development" index. And it takes modern education technology as observation points for teacher evaluation. It fully proves that the evaluation aim is to promote the development of teachers. And it provides reference for theoretical research and practice innovation for evaluation and development of teachers in applied undergraduate colleges.

\section{INVESTIGATION ON THE STATUS OF TEACHERS EVALUATION IN APPLIED UNDERGRADUATE UNIVERSITIES}

\section{A. Survey on Teacher Evaluation Cognition}

In order to promote the effective implementation of teacher evaluation work in applied undergraduate colleges and universities, this study conducts a questionnaire survey on the status quo of teacher evaluation in conjunction with the actual situation of applied universities. A total of 145 valid questionnaires were received. Among the 145 questionnaires received, 85 persons $(58.62 \%)$ considered that teacher evaluation were very important, ranking first. 57 people $(39.31 \%)$ considered that it would be more important, ranking the second. Two people $(1.38 \%)$ considered that it was less important, ranking the third. One person $(0.69 \%)$ considered that it wasn't important, ranking fourth. The statistical results show that everyone has a high degree of understanding of the importance of teacher evaluation in applied undergraduate colleges.

\section{B. Survey on the Purpose of Teacher Evaluation}

Aiming at the purpose of teacher evaluation in applied undergraduate colleges, we have carried on the investigation of ideal demand and actual operation. It is to understand the gap between the two. In the survey of ideal demand, the number of people who choose the evaluation purposes such as "improving the education and teaching quality", "promoting the development of teachers", "the basis of teachers' appointment, promotion, reward and punishment" ranks among the top three, which is $81.72 \%, 66.90 \%$ and $50.69 \%$ respectively. In the practical investigation, the number of people who choose the evaluation purpose of improving the quality of education and teaching still ranks first. However, the value decreases to $66.90 \%$. $57.93 \%$ of them chose "the basis of teacher appointment, promotion, reward and punishment", ranking up to the second. The proportion of people who chose to "promote the development of teachers" was $40.00 \%$. And the ranking dropped to the third. The results show that the evaluation purpose of "promoting teacher development" has not been embodied either in people's ideology or in practical operation. In addition, the reward and punishment of teacher evaluation 
plays a leading role in the actual operation. And there is a certain distance between the ideal needs and actual operation.

\section{Investigations on Individualization of Evaluation Indicators}

There are differences in teachers' age, teaching age, professional titles, disciplines and so on in applied undergraduate colleges and universities. In the investigation of ideal demand, the proportion of teachers' evaluation "should respect individual differences among teachers" is $79.31 \%$, ranking first. The proportion of choosing "indifferent" and "should not" was $11.03 \%$ and $9.66 \%$, ranking the second and third respectively. In the actual operation investigation of teacher evaluation, the proportion of "ignoring individual differences of teachers" was $48.28 \%$, ranking first. The proportion of "fully respecting the individual differences of teachers" is only $41.38 \%$. Obviously, in the actual operation of teacher evaluation, the degree of respecting for teachers' individual differences is not very high.

\section{Survey on Dimensions of Evaluation Indicators}

The results showed that the number of people who chose "work process", "work performance", "basic quality" and "teacher development" were in the top four positions, accounting for $86.90 \%, 69.66 \%, 59.31 \%$ and $54.48 \%$ respectively. Other options account for $6.9 \%$. And it may not be considered. Through practical investigation and theoretical research, "teacher development" is the key to promote the innovation of teacher evaluation and improve the quality of education and teaching. To this end, the "teacher development" would be integrated into the teacher evaluation system.

\section{E. Others}

In addition to the above-mentioned surveys, this study also carried out other research projects, including: the investigation on the degree of understanding on rewards and punishments and development of teacher evaluation; the investigation on the attribution of teacher evaluation; investigation on teachers' attitude to participating in evaluation activities; survey on teacher evaluation programmers; investigation on the selection of teacher evaluation subject; survey on teachers' understanding of current evaluation criteria; survey on teacher's satisfaction of current evaluation system or evaluation work. All the results of the survey provide a true and reliable basis for the reform and innovation of the teacher evaluation in applied undergraduate universities.

\section{EXISTING PROBLEMS AND IMPROVEMENT MEASURES OF TEACHER EVALUATION}

\section{A. Major Problems in Current Teacher Evaluation}

Through the investigation of the present situation, there is a certain gap between the ideal needs and the actual operation of teacher evaluation in the applied undergraduate colleges and universities. People still lack enough understanding and attention to the evaluation purpose of promoting the "teacher development". And the evaluation system still lacks the integrity, systematicness, dynamic and impartiality. First of all, on the operational level, we pay too much attention to the evaluation of rewards and punishments, and neglect the development of teacher evaluation. Secondly, the teacher evaluation index "sweeping approach" ignores the difference between different individual and corresponding evaluation index, the selection of the evaluation items to different evaluation subjects, and the adoption of evaluation methods to different evaluation indexes. Thirdly, it pays too much attention to the performance management of evaluation results and neglects the humanistic concern and timely feedback of the evaluation process. Fourth, we can't pay one-sided attention to the evaluation of teachers. However, it ignores the teacher's self-evaluation. And the diversified dimensions of the evaluation subject are not perfect and so on.

\section{B. Improvement Measures for Teacher Evaluation Innovation}

The teacher evaluation innovation in applied undergraduate colleges should be the combination of frontier and feasibility, static and dynamic, reward and punishment, development and qualitative evaluation. Aiming at the existing problems in the current evaluation, the following measures should be taken to improve the teacher evaluation in applied undergraduate colleges based on the development of modern educational technology. Firstly, the teacher evaluation system should be established in combination with the goals of running a school, the structure of teachers, the establishment of specialties and the training scheme. In order to promote teacher development, the first-level indexes of teacher evaluation have been improved from "basic qualities - work process-work performance" to "basic qualities -work process-work performance-teacher development", which provides solid basis and guarantee for the realization of the goal of running a school and the teacher development. Second, it should take the development of modern education technology as the observation point. It should integrate the online (network), micro-teaching counseling, Q \& A workload into the assessment of teacher's work process. It should integrate the teacher's courseware results, micro-curricular results and MOOC results into the assessment of teachers' performance. And then, it would adapt to the development of science and technology in the era. Third, it should make full use of modern science and technology to realize the construction of dynamic evaluation index system. Different evaluation subjects correspond to different evaluation methods and evaluation indicators. The evaluation results of different evaluation subjects have different weights. The evaluation indexes, standards and weights of different subjects should be different. These tedious and meticulous calculations can be accomplished by modern information technology, such as spss software, spreadsheet and so on. After working out the calculations program, they can respond to the change of the input condition, which greatly improves the efficiency and accuracy of the calculations Fourth, it should strengthen the humanistic management of teacher evaluation, and formulate 
a comprehensive, systematic, scientific and fair teacher evaluation program. We should do a good job in the selection, training and propaganda of the evaluation subjects. It is necessary to renew the evaluation concept, innovate the evaluation management and perfect the evaluation scheme. And the evaluation result would be more objective, fair, true and reliable.

\section{SCIENTIFIC CONSTRUCTION OF TEACHER EVALUATION SYSTEM}

\section{A. Chromatographic Structure of the Evaluation System}

The composition of the teacher evaluation system in applied undergraduate colleges is multi-faceted, which consists of the evaluation subject, the evaluation object, the evaluation index system and the evaluation management. The factors are infiltrated and intermingled with each other. The hierarchy is shown in "Fig. 1".

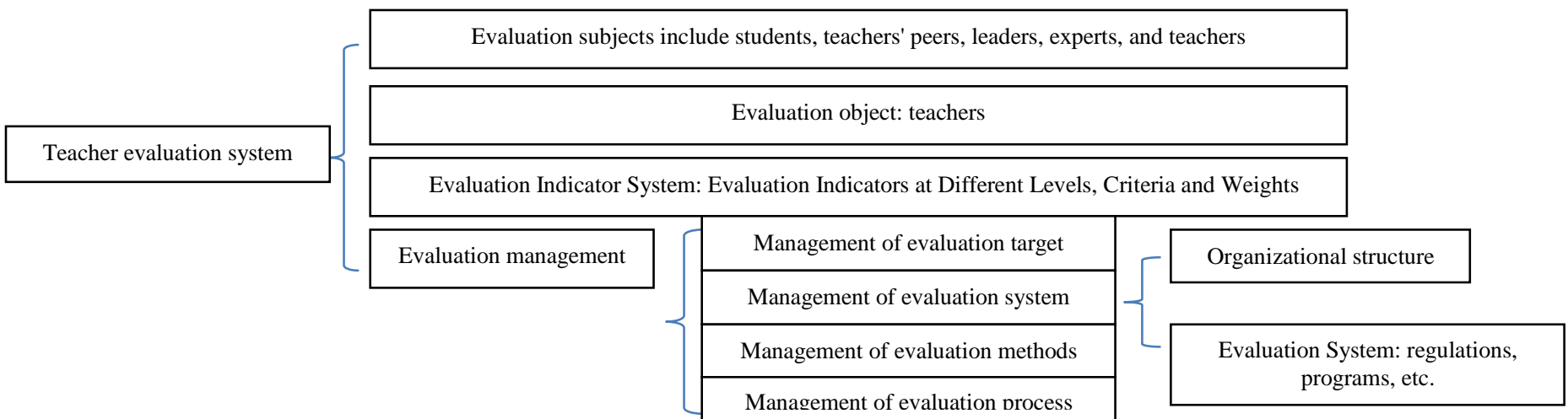

Fig. 1. Chromatographic structure of teacher evaluation system in applied undergraduate colleges and universities.

\section{B. The Confirmation of Evaluation Subjects and Their Weights}

Through questionnaires and theoretical research, it determines that the main body of teacher evaluation should consist of five parts such as students, teachers' peers, leaders, experts (supervisors) and teachers. In order to calculate the weight of each subject, the author invites four education experts and six front-line teachers to sort the importance of the above five evaluation subjects. According to the order, the evaluation subject in the first place is assigned to 1 . And the evaluation subject in the second place is assigned to 2 . With the same principle, the evaluation subject in the third, the fourth and the fifth respectively is assigned to $3,4,5$. If the order of importance is same, for example, "front-line teacher 2" considers that leaders, experts, teachers and students are equally important, the number of the above four evaluation subjects is $(1+2+3+4) / 4=2.5$. The judgement results of 4 experts and 6 teachers are shown in "Table I".

TABLE I. The JUdGEMENT Results of EVAluation SubJeCt's IMPORTANCE

First, we should use $X^{2}$ check. And the consistency of

\begin{tabular}{c|l|l|l|l|l}
\hline \multirow{2}{*}{$\begin{array}{c}\text { Surveyed } \\
\text { people }\end{array}$} & \multicolumn{5}{|c}{ The Assignment of Importance of Evaluation Subject } \\
\cline { 2 - 6 } Expert 1 & 1 Leaders & 2 Experts & 3 Peers & 4 Teachers & 5 Students \\
\hline Expert 2 & 2 & 1 & 2 & 5 & 3 \\
\hline Expert 3 & 2.5 & 3 & 4 & 5 & 1 \\
\hline Expert 4 & 1 & 2.5 & 2.5 & 5 & 2.5 \\
\hline Teacher 1 & 3 & 1 & 3 & 5 & 4 \\
\hline Teacher 2 & 2.5 & 2.5 & 2.5 & 5 & 2 \\
\hline Teacher 3 & 3 & 2 & 4 & 5 & 2.5 \\
\hline Teacher 4 & 2 & 1 & 3 & 5 & 1 \\
\hline Teacher 5 & 3 & 3 & 3 & 3 & 3 \\
\hline Teacher 6 & 3 & 2 & 1 & 4.5 & 4.5 \\
\hline rank sum $(R)$ & 26 & 20 & 30 & 46.5 & 27.5 \\
\hline weight (Wi) & 26 & 20 & 30 & 46.5 & 27.5 \\
\hline C
\end{tabular}
the judgement results is significantly tested by the "test" method. 


$$
\begin{gathered}
X^{2}=\frac{\sum R_{i}^{2}-\left(\sum R_{i}\right)^{2} / m}{1 / 12 m n(m+1)} \\
=\frac{26^{2}+20^{2}+30^{2}+46.5^{2}+27.5^{2}-(26+20+30+46.5+27.5)^{2} / 5}{1 / 12 \times 5 \times 10 \times(5+1)}=15.78
\end{gathered}
$$

$X^{2}$ Among them, $m$ is the number of evaluation subject. It is $5 . n$ is the number of judges who took part in the questionnaire. It is $10 . \mathrm{Ri}$ is the assignment sum (rank sum) corresponding to the evaluation subject of $i$. We could check $X_{0.01}^{2}(3)=11.34, \quad X^{2} \geq X_{0.01}^{2}(3)$, the results are consistent and significant. On the basis of this conclusion, the weight of each evaluation subject can be calculated by the method of "rank sum operation". The formula is as follows:

$$
W_{i}=\frac{2\left[(m+1) n-R_{i}\right]}{m n(m+1)}(i=1,2,3, \ldots, m)
$$

Among them, ${ }^{W}$ is the weight of evaluation subject of $i$. And $R_{i}$ is rank sum of evaluation of $i$. And the weight of each evaluation subject is calculated as shown in "Table II".

TABLE II. LIST OF WEIGHTS OF DifFERENT EVALUATION SUBJECTS

\begin{tabular}{c|l|l|l|l|l}
\hline \multirow{2}{*}{$\begin{array}{c}\text { Evaluation subject } \\
\text { Weight }\end{array}$} & \multicolumn{5}{|c}{ The category of evaluation subject } \\
\cline { 2 - 6 } & 1 Leaders & 2 Experts & 3 Peers & 4 Teachers & 5 Students \\
\hline weight $($ Wi) & 0.227 & 0.267 & 0.200 & 0.090 & 0.216 \\
\hline
\end{tabular}

\section{Evaluation Objects}

The evaluation object is the teacher. In the traditional sense, the teacher is the passive people who are evaluated by the others. With the continuous progress of modern educational thought, teachers' position has also risen from passivity to initiative. Their role in the process of teacher evaluation is multi-dimensional. First, they are evaluated by the others, namely the evaluation object. Secondly, in the peers' evaluation of teachers, they are the subject of evaluation. Third, in self-evaluation, they are both evaluators and people who are evaluated by the others. With the continuous improvement of teacher evaluation organizations, some teachers' representatives have to participate in the formulation, revision and improvement of the evaluation system. With the continuous reform and innovation of teacher evaluation, teachers' potential enthusiasm will be aroused. And their role in teacher evaluation will become more and more obvious.

\section{Teacher Evaluation Index System}

According to the basic principle of tree index system, and the basis of "basic quality", "work process", "work performance" and "teacher development", 19 secondary indexes and 56 tertiary indexes have been formed according to the method of decomposition and expert selection. The common methods for calculating the weight of evaluation indexes are expert opinion averaging method, Delphi method, rank sum operation method, analytic hierarchy process (AHP), logarithmic weighting method and so on. In this study, it uses the method of "rank sum". And the formula is shown in the following:

$$
\begin{gathered}
W_{i}=\frac{2\left[(m+1) n-R_{i}\right]}{m n(m+1)} \\
(i=1,2,3, \ldots, m)
\end{gathered}
$$

Among them, ${ }^{W_{i}}$ is the weight of $i_{\text {index. }} R_{i}$ is the rank sum of $i_{\text {index. }} m$ is the number of index. $n_{\text {is the number }}$ of experts. We could calculate the weights of four first-grade index. And then, we could get $W_{1}=0.240, W_{2}=0.390$, $W_{3}=0.260, W_{4}=0.110$. With the same principle, we could calculate the weight of second-grade index, third-grade index. And in the end, we would get synthetic weight. The evaluation index system of applied undergraduate colleges and universities is shown in "Table 3". 
TABLE III. EVALUATION INDEX SYSTEM OF TEACHERS IN APPLIED UNDERGRADUATE COLLEGES

\begin{tabular}{|c|c|c|c|c|}
\hline $\begin{array}{l}\text { First-grade } \\
\text { indexes }\end{array}$ & Second-grade index & $\begin{array}{l}\text { synthetic } \\
\text { weight }\end{array}$ & Third-grade index & $\begin{array}{l}\text { synthetic } \\
\text { weight }\end{array}$ \\
\hline \multirow{14}{*}{$\begin{array}{c}1 \\
\text { basic quality } \\
0.240\end{array}$} & \multirow{2}{*}{$\begin{array}{l}11 \text { ideological and ethical } \\
\text { standards } \\
0.310\end{array}$} & \multirow{2}{*}{0.074} & 111 political thought 0.157 & 0.038 \\
\hline & & & 112 professional ethics 0.483 & 0.036 \\
\hline & \multirow{4}{*}{$\begin{array}{l}12 \text { knowledge structure } \\
0.350\end{array}$} & \multirow{4}{*}{0.084} & 121 subject-involved knowledge 0.370 & 0.031 \\
\hline & & & 122 conditional knowledge 0.290 & 0.023 \\
\hline & & & 123 practical knowledge 0.190 & 0.016 \\
\hline & & & 124 scientific and cultural knowledge 0.150 & 0.013 \\
\hline & \multirow{6}{*}{$\begin{array}{l}13 \text { capability and quality } \\
0.220\end{array}$} & \multirow{6}{*}{0.053} & 131 teaching ability 0.281 & 0.015 \\
\hline & & & 132 capacity for scientific research 0.205 & 0.011 \\
\hline & & & 133 ability to organize and manage 0.114 & 0.006 \\
\hline & & & 134 Practical guidance 0.190 & 0.010 \\
\hline & & & 135 modern educational skill 0.105 & 0.006 \\
\hline & & & 136 innovation ability 0.105 & 0.006 \\
\hline & \multirow{2}{*}{$\begin{array}{l}14 \text { physical and mental quality } \\
0.120\end{array}$} & \multirow[b]{2}{*}{0.029} & 141 physical quality 0.567 & 0.016 \\
\hline & & & 142 psychological traits 0.433 & 0.013 \\
\hline \multirow{18}{*}{$\begin{array}{c}2 \\
\text { work process } \\
0.390\end{array}$} & \multirow{4}{*}{$\begin{array}{l}\text { 21 Classroom teaching } \\
0.276\end{array}$} & \multirow{4}{*}{0.108} & 211 teaching contents 0.290 & 0.031 \\
\hline & & & 212 teaching methods 0.230 & 0.025 \\
\hline & & & 213 teaching method 0.150 & 0.016 \\
\hline & & & 214 teaching effect 0.330 & 0.036 \\
\hline & \multirow{3}{*}{$\begin{array}{l}22 \text { research work } \\
0.233\end{array}$} & \multirow{3}{*}{0.091} & 221 scientific research attitude 0.450 & 0.041 \\
\hline & & & 222 research investment 0.317 & 0.029 \\
\hline & & & 223 research features 0.233 & 0.021 \\
\hline & \multirow{3}{*}{$\begin{array}{l}23 \text { Preparation before class } \\
0.195\end{array}$} & \multirow{3}{*}{0.076} & 231 preparation for courseware 0.442 & 0.034 \\
\hline & & & 232 Facility preparation 0.308 & 0.023 \\
\hline & & & 233 Relevant information reserve 0.250 & 0.019 \\
\hline & \multirow{3}{*}{$\begin{array}{l}24 \text { guidance and } \mathrm{Q} \& \mathrm{~A} \\
\text { (network) } \\
0.129\end{array}$} & \multirow{3}{*}{0.050} & 241 work correction and registration 0.350 & 0.018 \\
\hline & & & 242 guidance and Q\&A (network) 0.330 & 0.016 \\
\hline & & & 243 thesis guidance 0.330 & 0.016 \\
\hline & \multirow{3}{*}{$\begin{array}{l}25 \text { examination work } \\
0.105\end{array}$} & \multirow{3}{*}{0.041} & 251 test paper quality 0.467 & 0.019 \\
\hline & & & 252 overall appearance on the paper 0.300 & 0.012 \\
\hline & & & 253 Reading and Appraisal of paper 0.233 & 0.010 \\
\hline & \multirow{2}{*}{$\begin{array}{l}26 \text { Social service work } \\
0.062\end{array}$} & \multirow{2}{*}{0.024} & 261 Social service attitude 0.500 & 0.012 \\
\hline & & & 262 Social service process 0.500 & 0.012 \\
\hline
\end{tabular}




\begin{tabular}{|c|c|c|c|c|}
\hline $\begin{array}{l}\text { First-grade } \\
\text { indexes }\end{array}$ & Second-grade index & $\begin{array}{c}\text { Synthetic } \\
\text { weight }\end{array}$ & Third-grade index & $\begin{array}{c}\text { synthetic } \\
\text { weight }\end{array}$ \\
\hline \multirow{17}{*}{$\begin{array}{c}3 \\
\text { work } \\
\text { performance } \\
0.260\end{array}$} & \multirow{3}{*}{$\begin{array}{l}31 \quad \text { classroom } \\
\text { performance } \\
0.278\end{array}$} & \multirow{3}{*}{0.072} & 311 Teaching workload 0.317 & 0.023 \\
\hline & & & 312 teaching results 0.317 & 0.023 \\
\hline & & & 313 teaching features 0.366 & 0.026 \\
\hline & \multirow{5}{*}{$\begin{array}{l}32 \quad \text { Scientific } \\
\text { performance } \\
0.218\end{array}$} & \multirow{5}{*}{0.057} & 321 undertaking project 0.227 & 0.013 \\
\hline & & & 322 publish papers 0.213 & 0.012 \\
\hline & & & 323 publish works 0.173 & 0.010 \\
\hline & & & 324 academic exchanges 0.260 & 0.015 \\
\hline & & & 325 social impact 0.127 & 0.007 \\
\hline & \multirow{2}{*}{$\begin{array}{l}33 \text { Preparation performance } \\
\text { before class } \\
0.195\end{array}$} & \multirow{2}{*}{0.051} & 331 Teaching document workload 0.467 & 0.024 \\
\hline & & & 332 courseware results 0.533 & 0.027 \\
\hline & \multirow{2}{*}{$\begin{array}{l}34 \text { coaching performance } \\
\text { (network) } 0.128\end{array}$} & \multirow{2}{*}{0.033} & 341 coaching workload 0.045 & 0.015 \\
\hline & & & 342 coaching results 0.055 & 0.018 \\
\hline & \multirow{3}{*}{$\begin{array}{l}35 \text { Test performance } \\
0.105\end{array}$} & \multirow{3}{*}{0.027} & 351 workload of setting a theme 0.342 & 0.009 \\
\hline & & & 352 Marking workload 0.317 & 0.009 \\
\hline & & & 353 test results 0.342 & 0.009 \\
\hline & \multirow{2}{*}{$\begin{array}{l}\text { 36 Social service performance } \\
0.080\end{array}$} & \multirow{2}{*}{0.02} & 361 Participation in social services 0.500 & 0.010 \\
\hline & & & 362 Social service effect 0.500 & 0.010 \\
\hline \multirow{7}{*}{$\begin{array}{c}4 \\
\text { teacher } \\
\text { development } \\
0.110\end{array}$} & \multirow{2}{*}{$\begin{array}{l}41 \text { lifelong learning } \\
0.483\end{array}$} & \multirow{2}{*}{0.053} & 411 lifelong learning consciousness 0.533 & 0.028 \\
\hline & & & 412 Lifelong learning habit 0.467 & 0.025 \\
\hline & \multirow{3}{*}{$\begin{array}{l}42 \text { continues education } \\
0.183\end{array}$} & \multirow{3}{*}{0.020} & 421 Degree courses 0.316 & 0.006 \\
\hline & & & 422 Scientific research activities 0.342 & 0.007 \\
\hline & & & 423 business refresher training 0.342 & 0.007 \\
\hline & \multirow{2}{*}{$\begin{array}{l}43 \text { exchange and reflection } \\
0.334\end{array}$} & \multirow{2}{*}{0.037} & 431 communication 0.483 & 0.018 \\
\hline & & & 432 teaching reflection 0.517 & 0.019 \\
\hline
\end{tabular}

For the above 56 three-level evaluation indicators, we can use the collective method to determine its applicable evaluation subjects by voting. For example, with item 112 "Professional Ethics", the evaluation subjects determined by voting are leaders, experts, peers and students. With item 322 "Publishing the paper", the determined evaluation subjects are leaders, experts, peers and teachers. In addition, the evaluation methods applicable to each evaluation indicator are not identical. And the evaluation should be flexible according to the actual situation.

\section{E. Evaluation Management}

Management depends on people, and the core of teacher evaluation management is evaluation organization. The organizational structure of current evaluation should be multi-level. And its functions are no longer carried out independently by a certain functional department of the college as in the past. The scientific and technological content of current evaluation activities is becoming more advanced. The object of evaluation is becoming more and more targeted. The fitness of evaluation index system is more and more flexible. The data processing workload is more and more heavy. Therefore, the evaluation organization needs to have a batch of professional staff. They can understand the business and do the management well. They can deal with the coordination and changes. Also, they should understand the orientation of the college, the training goal and the development of the discipline specialty at all times. On the basis, it should carry out the evaluation activities of teachers at all stages. Evaluation organizations should complete the development of evaluation systems including evaluation implementation programs and evaluation management regulations. And they also should provide evaluation training, publicity, education and psychological counseling to evaluators at the appropriate time.

\section{CONCLUSION}

To sum up, based on "teacher development", modern education technology and advanced science and technology, the dynamic teacher evaluation system can make the evaluation result be more objective, truthful, comprehensive and fair. This is of great significance for arousing teachers' enthusiasm. And it would promote their professional development. Also, it is of great significance for strengthening the construction of teachers' ranks and implementing the strategic goal of "strengthening schools with talents". 


\section{REFERENCES}

[1] Feng Hongqi. Research on the sustainable development of teacher under the perspective of modern educational technology [J]. Continue Education Research, 2016(08). 封红旗. 现代教育技术视野下教师可 持续发展创新探究 $[J]$.继续教育研究.2016(08).

[2] Wang Xiaoling. Educational Statistics [M]. Shanghai: East China Normal University Press, 2015. 王孝玲.教育统计学 $[M]$.上海: 华东 师范大学出版社, 2015.

[3] Zeng Qingtao. Research on the evaluation system of sports teachers in China [D]. Henan: Doctoral dissertation of Henan University, 2011. 曾庆涛.我国体育教师评价体系研究[D].河南: 河南大学博士学位 论文， 2011.

[4] Yao Suping. Thinking on the role of teachers in the condition of modern education technology [J]. Caizhi. 2016(29). 姚苏玶. 现代教 育技术条件下教师角色定位的思考[J].才智.2016(29).

[5] Sun Hechuan. A comparative study of teacher evaluation index system between China and the United States [J]. Research in Education Development, 2011(3). 孙河川.中美教师评价指标体系的 比较研究 $[\mathrm{J}]$.教育发展研究, 2011(3). 